\title{
Potensi Peternakan Ayam Buras Sebagai Usaha Ekonomi Masyarakat Pedesaan Di Provinsi Sumatera Barat
}

\author{
Rahmi Wati \\ Jurusan Produksi Ternak Fakultas Peternakan Universitas Andalas, Padang
}

\begin{abstract}
This paper discussed the potency of kampong chickens as the main source of employment and income in West Sumatra. From about 2 millions of Indonesian kampong chickens in 2005, about 5.725.515 were found in West Sumatra. In terms of egg production, body weight gain and feed utilization efficiency, the productivity and biological performances of kampong chickens were much lower than that of hybrid chickens. On the other hand, the product of kampong chickens, e.g. egg and meat, in the market were normally valued higher by the consumers because of their better taste and healthier product. In addition, kampong chickens could be intensively reared in lower production cost becanse of their lower nutritional and management requirements. Results of some studies has shown that production of kampong chicken might be directed for business unit as back yard or intensively farming especially in supporting of economic development in the rural community.
\end{abstract}

Key words: kampong chicken, rural economic development, agribusiness.

\section{Pendahuluan}

Dalam berbagai Rencana Pembangunan Pertanian, subsektor peternakan tetap merupakan salah satu sumber pertumbuhan baru, walaupun belum mendapat perhatian yang cukup besar dibandingkan dengan sub sektorsub sektor lainnya. Pembangunan paternakan diarahkan untuk meningkatkan pendapatan dan kesejahteraan peternak, meningkatkan pemenuhan konsumsi protein hewani asal ternak, menyediakan bahan baku industri, menciptakan lapangan kerja, meningkatkan peranan lembaga peternakan dan mewujudkan tercapainya keseimbangan antara pemanfaatan dan pelestarian sumber daya alam. Tingkat investasi pemerintah pada usaha peternakan relatif kecil, dari sub sektor peternakan pemerintah dan swasta umumnya melakukan investasi pada industri ayam ras.
Komoditas ayam ras telah berkembang sangat pesat dalam 20 tahun terakhir antara lain karena dukungan impor bibit unggul, pertumbuhan industri pakan dan pembibitan di dalam negeri. Komoditas peternakan lainnya kurang mendapat perhatian, seperti sapi potong, ruminansia kecil dan unggas lainnya seperti ayam buras. Ayam buras adalah sumberdaya domestik yang dimiliki rakyat Indonesia yang umum dipelihara oleh petani/peternak di pedesaan. Populasi ayam buras untuk Provinsi Sumatera Barat mengalami peningkatan dari 7,510 juta ekor pada tahun 2000 meningkat menjadi 7,738 juta ekor pada tahun 2004. Untuk konsumsi daging ayam buras di Provinsi Sumatera Barat tercatat sebesar 4477 ton. Angka ini memperihatkan bahwa Sumatera Barat memiliki potensi ternak ayam buras yang relatif besar. 
Ayam buras dikenal sebagai ternak yang mempunyai daya hidup yang tinggi, dapat hidup diberbagai wilayah dengan perbedaan kondisi iklim yang ekstrim. Selain itu juga mempunyai kemampuan untuk hidup dalam kondisi pakan dengan kandungan nutrisi yang rendah. Ayam buras di Indonesia dapat ditemukan di seluruh Indonesia khususnya dipelihara di daerah pedesaan. Pada umumnya ternak ini dipelihara secara ektensif sebagai usaha sampingan atau sebagai tabungan. Pemasaran ayam buras di pedesaan pun tidak sulit, karena selalu ada pedagang keliling yang bersedia membeli ayam buras.

Pada sisi lain ayam buras sebagai ternak yang belum mendapat sentuhan teknologi pengembangan genetis, mempunyai beberapa kelemahan dilihat dari berbagai perspektif ckonomi seperti kematian anak ayam yang tinggi, daya tumbuh yang lambat dan produksi telur yang sangat rendah. Pada sisi permintaan, ayam buras termasuk bahan makanan yang sudah populer di kalangan masyarakat. Djatmiko dan Sugiharta (1986) melaporkan bahwa terdapat preferensi yang tinggi dari masyarakat terhadap daging dan telur ayam buras. Pasar yang terbuka untuk ayam buras ini bahkan belum dapat memenuhi kebutuhan konsumen baik pada daging maupun telurnya, untuk permintaan ayam potong misalnya untuk DKI Jakarta sekitar 70.000 ekor per hari (Nataamijaya, 1993). Dengan demikian, potensi ayam buras yang tinggi didukung pula oleh permintaan yang juga tinggi serta merupakan usaha yang sudah populer dikalangan masyarakat, ternyata belum berkembang menjadi suatu industri yang patut diketengahkan.

Dari uraian tersebut di atas dapat dirumuskan tema sentral penelitian sebagai berikut: Sumatera Barat memiliki cukup banyak sumberdaya domestik yang sampai saat ini telah diolah antara lain adalah lahan, tenaga kerja dan sumberdaya lainnya. Akan tetapi ternak ayam buras belum digali secara mendalam padahal ayam buras sangat potensial untuk dikembangkan scbagai usaha ekonomi. Jumlahnya yang sudah mencapai 7,738 juta ekor dengan pemilikan yang tersebar secara merata dan telah merupakan salah satu sumber pendapatan rumah tangga di pedesaan. Akan tetapi ternak ayam buras ini memiliki beberapa sifat yang tidak menguntungkan antara lain sistem pemeliharaan yang masih tradisional, daya produksi yang masih rendah, konversi makanan yang tinggi serta angka kematian yang juga masih tinggi.

Sementara pada sisi lain, permintaan masyarakat terhadap ternak ayam buras ini sangat tinggi. Telah dilaporkan pula, pada beberapa dacrah secara terbatas telah dimulai pemeliharaan ayam buras secara intensif yang diikuti dengan berbagai program pengembangan ayam buras sebagai usaha ekonomi rakyat. Namun demikian, ayam buras belum memperlihatkan diri sebagai suatu industri. Oleh karena itu menjadi pertanyaan utama mengapa usaha ayam buras ini tidak berkembang menjadi suatu industri rakyat.

\section{Tinjauan Umum Ayam Buras}

Ayam buras merupakan jenis unggas yang masih bersifat alami dalam arti kata belum mendapatkan perlakuan perbaikan genetis. Sifatsifat yang menguntungkan dari segi ekonomi yang dimiliki ayam buras relatif sedikit dibandingkan ayam ras, baik dalam produksi telur maupun kemampuan menghasilkan daging. 
Namun demikian ayam buras merupakan ternak yang sudah populer di kalangan masyarakat konsumen sebagai jenis penghasil daging dan telur yang digemari. Atas dasar itu, adanya dorongan permintaan ini ikut mempengaruhi perkembangan pemeliharaan ayam buras. Ayam buras merupakan salah satu ternak unggas lokal yang menyebar luas di Indonesia dan umum dipelihara oleh petani pedesaan. Tujuan pemeliharaan oleh masyarakat pedesaan belum spesifik, biasanya sebagai penghasil telur sekaligus penghasil daging bahkan juga sebagai tabungan.

Ayam buras mempunyai potensi genetis yang relatif rendah, demikian pula cara pemeliharaan dan pemberian pakannya masih tradisional, yang mengakibatkan rendahnya produksi ayam buras. Dengan demikian dapat dikatakan bahwa ayam buras mempunyai kemampuan genetis yang relatif rendah sehingga pengembangan sangat tergantung pada "profit margin" yang diperoleh peternak. Pada sisi lain, peternak menghadapi potensi pasar yang luas dan ayam buras mulai dipelihara secara semi intensif dan intensif. Perubahan ini diperkirakan sebagai akibat harga output yang tinggi dan produktivitas yang masih dapat ditingkatkan (pada sistem pemeliharaan intensif) sehingga dapat memberikan keuntungan. Menurut Nataamijaya (1993) produtivitas akan meningkat pada pemeliharaan secara intensif. Masalahnya adalah apakah dalam hal biaya atau secara ekonomi usaha ayam buras efisien.

\section{Asal Usul Ayam Kampung/Buras}

Menurut Hutt dan Jull dalam Mansyur (1985) terdapat empat spesies ayam hutan yang digolongkan dalam genus Gallus, antara lain : (1)
Ayam Hutan Merah (Gallus gallus Lineaus); (2) Ayam Hutan Ceylon (Gallus lavayetti Lesson); (3) Ayam Hutan Abu-abu (Gallus sonneratti Temnick) dan (4) Ayam Hutan Hijau (Gallus varius Shaw). Ayam hutan Hijau dikenal juga dengan nama Ayam Hutan Jawa (Gallus furcatus atau Gallus vanicus) yang terdapat di Pulau Jawa dan pulau-pulau lainnya. Dari keempat jenis tersebut terjadi perkawinan, lalu para penemu dan pemelihara ayam-ayam liar menjinakkan dan mengembang-biakannya sehingga menjadi ayam-ayam piaraan yang populer dikenal sebagai ayam buras.

Menurut Sarwono (1996), sebutan ayam kampung karena umumnya ayam tersebut dipelihara secara ekstensif, dibiarkan lepas berkeliaran di halaman, di lapangan, kebun, dan tempat-tempat lain di sekitar kampung atau daerah pemukiman manusia. Selanjutnya, Marhijanto (1996) menyebut ayam kampung karena ayam ini sejak zaman dulu sampai sekarang umumnya dipelihara oleh orang-orang desa, di kampung-kampung secara liar atau umbaran. Adanya perbaikan dalam cara pemeliharaan ayam kampung ini kemudian disebut ayam buras (bukan ras) dengan tujuan untuk membedakan dengan ayam ras yang berasal dari luar negeri.

\section{Populasi dan Perkembangan Ayam Buras}

Perkembangan populasi ternak ayam buras di Provinsi Sumatera Barat, sejak tahun 2000 sampai dengan tahun 2005 terlihat pada Tabel 1. Pada Tabel 1 dapat kita lihat bahwa populasi ternak unggas di Provinsi Sumatera Barat berfluktuasi. Populasi ternak ayam buras dari tahun 2001 sampai dengan tahun 2003 cenderung 
meningkat dengan laju pertumbuhan yang berfluktuasi. Pada tahun 2001 populasi ayam buras tercatat sebesar 7 604626 ekor, kemudian meningkat menjadi 7877468 ekor pada tahun 2003, tetapi pada tahun 2004 dan 2005 populasi ternak ayam buras di Provinsi Sumatera Barat mengalami penurunan.

Peningkatan populasi ayam buras antara lain disebabkan adanya kebijaksanaan yang ditempuh pemerintah dalam menunjang perkembangan usaha ternak ayam buras yang telah dirintis sejak tahun 1985 dengan dikeluarkannya SK Menteri Pertanian/Ketua Badan Pengendali Bimas No, 17/SK/1/1985 tentang Intensifikasi Ayam Bukan Ras (INTAB), kemudian dilanjutkan dengan proyek-proyek pemerintah dalam rangka peningkatan populasi dan produksi daging dan telur antara lain INVAK (Intensifikasi Vaksinasi), Penanggulangan Peternak Berpendapatan Rendah, Gema Proteina, dan lain-lain. Sedangkan rendahnya laju pertumbuhan populasi ayam buras adalah karena: (1) Adanya wabah ND (Newcastle Disease), (2) Mulai mewabahnya penyakit flu burung yang mengakibatkan ternak mati secara mendadak, dan (3) Dampak dari krisis moneter yang masih dirasakan oleh masyarakat sampai sekarang menye- babkan kontinuitas peningkatan produktivitas sulit dilakukan, karena input yang diberikan tidak kontinyu dan sangat tergantung dari kondisi sosial ekonomi peternak. Pada waktu peternak memiliki modal, maka petemak akan membeli pakan, obat, perlengkapan kandang dan lain-lain, akan tetapi pada saat keadaan ekonominya sedang memburuk, maka input yang diberikan bisa terhenti, bahkan mereka bisa menjual ternaknya.

\section{Distribusi Populasi Ayam Buras Menurut Geografi}

Sebaran populasi ayam buras menurut kabupaten dan kota di Provinsi Sumatera Barat tahun 2005 disajikan pada Tabel 2. Pada Tabel 2 bisa kita lihat bagaimana penyebaran ternak unggas (ayam buras, ayam ras pedaging, ayam ras petelur dan itik) di Provinsi Sumatera Barat. Berdasarkan tabel tersebut terlihat bahwa populasi ayam buras tersebar di semua kabupaten dan kota. Kabupaten Padang Pariaman merupakan kabupaten dengan tingkat populasi ayam buras yang paling tinggi dibandingkan dengan kabupaten dan kota lainnya yang ada di Sumatera Barat yaitu 1 034664 ekor.

Tabel 1. Populasi Ternak Unggas di Provinsi Sumatera Barat Tahun 2001 - 2005 .

\begin{tabular}{lrrrr}
\hline \multirow{2}{*}{ Tahun } & \multicolumn{5}{c}{ Jenis Ternak Unggas } \\
\cline { 2 - 5 } & Ayam Ras Petelur & Ayam Ras Pedaging & Ayam Buras & \multicolumn{1}{c}{ Itik } \\
\hline 2001 & 3691645 & 10653726 & 7604626 & 1744732 \\
2002 & 4590555 & 10882230 & 7784059 & 1795425 \\
2003 & 4706628 & 10608542 & 7877468 & 992621 \\
2004 & 5337255 & 12804118 & 7737703 & 852141 \\
2005 & 5608482 & 11357781 & 5725515 & 985442 \\
\hline Sumber : Statistik Peternakan Provinsi Sumater Bat
\end{tabular}


Tabel 2. Populasi ternak Ayam Buras Menurut Jenisnya Tahun 2005

\begin{tabular}{llrrrr}
\hline No. & Kabupaten/Kota & Ayam Buras & $\begin{array}{c}\text { Ayam Ras } \\
\text { Pedaging }\end{array}$ & $\begin{array}{c}\text { Ayam Ras } \\
\text { Pctelur }\end{array}$ & \multicolumn{1}{c}{ Itik } \\
\hline I & Kabupaten & & & & \\
\hline 1 & Pesisir Selatan & 756521 & 122550 & 55666 & 65127 \\
2 & Solok & 408631 & 36886 & 47900 & 114514 \\
3 & Sawahlunto Sijunjung & 379378 & 575550 & 13760 & 30842 \\
4 & Tanah Datar & 491735 & 160060 & 379435 & 143469 \\
5 & Padang Pariaman & 1034664 & 2437350 & 202800 & 116800 \\
6 & Agam & 314420 & 25310 & 136100 & 91267 \\
7 & Limapuluh Kota & 750784 & 608550 & 3586478 & 126046 \\
8 & Pasaman & 213388 & 47121 & 9250 & 65525 \\
9 & Mentawai & 41845 & 650 & 0 & 1888 \\
10 & Solok Selatan & 103530 & 12540 & 7920 & 34512 \\
11 & Pasaman Barat & 163290 & 129960 & 175200 & 13541 \\
12 & Dharmasraya & 164475 & 110360 & 3900 & 9567 \\
& & & & & \\
\hline II & Kota & & & & \\
\hline 13 & Padang & 439125 & 4602785 & 539622 & 47043 \\
14 & Solok & 179702 & 67165 & 17601 & 19510 \\
15 & Sawahlunto & 92482 & 25400 & 4000 & 6732 \\
16 & Padang Panjang & 14008 & 9055 & 0 & 10632 \\
17 & Bukittinggi & 26768 & 7489 & 0 & 3015 \\
18 & Payakumbuh & 115540 & 2119400 & 410850 & 80814 \\
19 & Pariaman & 35229 & 259600 & 0 & 4598 \\
\hline Sumber : Statistik Peternakan Provinsi Sumatera Barat, 2006 & & &
\end{tabular}

Perbandingan populasi ayam buras dengan ayam ras pedaging di Kabupaten Padang Pariaman adalah 1 $: 2,4$. Selain itu pada Tabel 2 bisa kita lihat juga bahwa pada beberapa kabupaten dan kota populasi ayam burasnya lebih banyak dibandingkan dengan populasi unggas lainnya, misalnya di Kabupaten Pesisir Selatan jumlah ayam burasnya 756521 ekor sementara populasi ayam ras pedagingnya 122550 ekor dan unggas lainnya lebih rendah lagi.

Pada Tabel 3 berikut bisa kita lihat penyebaran dari rumah tangga yang memelihara unggas. Berdasarkan data yang ada pada tabel tersebut terlihat bahwa jumlah rumah tangga yang memelihara ayam buras lebih banyak jika dibandingkan dengan unggas lainnya, Kabupaten Limapuluh Kota merupakan kabupaten dengan jumlah rumah tangga yang memelihara ternak ayam buras paling banyak dari semua kabupaten dan kota yang ada di Provinsi Sumatera Barat yaitu 56189 kepala keluarga. Kemudian diikuti oleh Kota Padang dengan jumlah Kepala keluarga pemelihara ternak ayam buras sebanyak 49735 .

Berdasarkan pada Tabel 2 dan Tabel 3 bisa kita lihat bahwa jumlah rumah tangga yang memelihara ternak ayam buras lebih banyak dibandingkan dengan unggas lainnya, tetapi jumlah populasinya ternak ayam buras populasinya masih sedikit jika dibandingkan dengan ternak ayam ras pedaging. Hal ini berarti bahwa ternak ayam buras masih diusahakan dalam 
skala yang kecil dan pemeliharaanya juga masih secara tradisional atau ekstensif, selain itu ternak ayam buras merupakan usaha peternakan sampingan.

\section{Sifat-Sifat Ayam Buras Sebagai Bahan Konsumsi}

Sebagaimana umumnya negara sedang berkembang yang mempunyai ciri konsumsi masyarakat yang relatif rendah terhadap daging, telur dan susu, maka masyarakat Indonesia pun tidak terkecuali. Tabel 4 memperlihatkan persentase konsumsi berbagai jenis daging dan telur penduduk Sumatera Barat pada tahun 2005.

Data - data yang ditampilkan pada Tabel 4 memperlihatkan bahwa daging sapi merupakan jenis daging dengan jumlah konsumsi paling tinggi di Provinsi Sumatera Barat. Sementara itu konsumsi daging ayam buras menduduki peringkat ke empat setelah daging sapi, daging ayam ras dan jeroan dengan jumlah konsumsi 3312 ton ( $11,58 \%$ dari total konsumsi daging). Hal ini menggambarkan bahwa tingkat permintaan konsumen terhadap daging ayam buras cukup tinggi di Provinsi Sumatera Barat.

Tabel 3. Distribusi Rumah Tangga Pemelihara Ternak Unggas di Provinsi Sumatera Barat Tahun 2005

\begin{tabular}{|c|c|c|c|c|c|}
\hline No. & Kabupaten/Kota & Ayam Buras & $\begin{array}{l}\text { Ayam Ras } \\
\text { Pedaging }\end{array}$ & $\begin{array}{c}\text { Ayam Ras } \\
\text { Petelur }\end{array}$ & Itik \\
\hline I & Kabupaten & & & & \\
\hline 1 & Pesisir Selatan & 40295 & 37 & 7 & 4753 \\
\hline 2 & Solok & 36056 & 17 & 7 & 8909 \\
\hline 3 & Sawahlunto Sijunjung & 15921 & 205 & 27 & 2391 \\
\hline 4 & Tanah Datar & 27767 & 124 & 146 & 5416 \\
\hline 5 & Padang Pariaman & 37695 & 331 & 15 & 2756 \\
\hline 6 & Agam & 28888 & 41 & 22 & 7309 \\
\hline 7 & Limapuluh Kota & 56189 & 447 & 733 & 4606 \\
\hline 8 & Pasaman & 11318 & 139 & 454 & 3109 \\
\hline 9 & Mentawai & 4178 & 3 & 0 & 181 \\
\hline 10 & Solok Selatan & 11945 & 35 & 7 & 3746 \\
\hline 11 & Pasaman Barat & 12727 & 1396 & 4 & 1452 \\
\hline 12 & Dharmasraya & 9821 & 85 & 5 & 700 \\
\hline II & Kota & & & & \\
\hline 13 & Padang & 49735 & 401 & 14 & 2082 \\
\hline 14 & Solok & 1051 & 91 & 18 & 337 \\
\hline 15 & Sawahlunto & 4735 & 20 & 3 & 475 \\
\hline 16 & Padang Panjang & 1164 & 117 & 0 & 353 \\
\hline 17 & Bukittinggi & 2616 & 9 & 0 & 164 \\
\hline 18 & Payakumbuh & 9382 & 230 & 152 & 911 \\
\hline 19 & Pariaman & 4355 & 36 & 0 & 76 \\
\hline
\end{tabular}

Sumber : Statistik Peternakan Provinsi Sumatera Barat, 2006 
Tabel 4. Distribusi Konsumsi Berbagai Jenis Daging dan Telur di Provinsi Sumatera Barat Tahun 2005.

\begin{tabular}{|c|c|c|c|}
\hline No & Jenis Bahan & $\begin{array}{l}\text { Jumlah Konsumsi } \\
\text { (Ton) }\end{array}$ & $\begin{array}{c}\text { Persantase Distribusi } \\
\text { Konsumsi } \\
(\%)\end{array}$ \\
\hline \multirow[t]{12}{*}{ I. } & Daging & & \\
\hline & Daging Sapi & 8947 & 31,28 \\
\hline & Daging Kerbau & 1748 & 6,11 \\
\hline & Daging Kambing & 713 & 2,49 \\
\hline & Daging Domba & 8 & 0.03 \\
\hline & Daging Babi & 214 & 0,75 \\
\hline & Daging Kuda & 5 & 0,02 \\
\hline & Daging Ayam Buras & 3312 & 11,58 \\
\hline & Daging Ayam Ras & 7770 & 27,16 \\
\hline & Daging Itik & 281 & 0,98 \\
\hline & Jeroan Semua Jenis & 5605 & 19,60 \\
\hline & Jumlah & 28603 & 100 \\
\hline \multirow[t]{5}{*}{ II } & Telur & & \\
\hline & Telur Ayam Buras & 2615 & 9,96 \\
\hline & Telur Ayam Ras & 18993 & 72,36 \\
\hline & Telur itik & 4641 & 1768 \\
\hline & Jumlah & 26249 & 100 \\
\hline
\end{tabular}

Sumber : Statistik Petemakan Provinsi Sumatera Barat, 2006

Untuk telur ada 3 jenis yang dikonsumsi oleh masyarakat Sumatera Barat yaitu telur ayam buras, telur ayam ras dan telur itik. Dari ketiga jenis telur tersebut jumlah konsumsi telur ayam ras paling banyak, setelah itu baru telur ayam buras dengan jumlah konsumsi 2615 ton atau sekitar 9, $96 \%$ dari total konsumsi telur.

Menurut data BPS terjadi penurunan tingkat konsumsi daging pada tahun 2005. Penurunan ini terjadi karena perekonomian masyarakat yang masih belum stabil sehingga terjadi penurunan hampir pada semua jenis makanan terutama yang berasal dari hewan. Tingkat konsumsi daging ayam buras terutama di pedesaan relatif lebih tinggi dibandingkan dengan ayam ras.

Menurut Sri Mulatsih dan Pambudy (1997), pola konsumsi selain ditentukan oleh komoditi dan tingkat pendapatan juga dipengaruhi oleh selera dan lingkungan. Oleh karena itu di dacrah yang banyak peternak tradisional yang memelihara ayam buras misalnya maka daging ayam buras akan lebih banyak dikonsumsi dibandingkan jenis daging lainnya. Sementara, Daslina (1992) juga melaporkan bahwa masyarakat di pedesaan umumnya mengkonsumsi daging yang berasal dari produksi sendiri yang sebagian besar merupakan ayam buras.

Dibandingkan ayam ras, ayam buras memiliki beberapa kelebihan. Hal ini terlihat dari terdapatnya preferensi yang tinggi dari masyarakat terhadap baik daging maupun telur ayam buras (Djatmiko dan Sugiharta, 1986). Konsumen misalnya, lebih menyukai daging ayam buras walaupun harganya lebih tinggi, antara 
lain karena : (1) Daging ayam dinilai bermutu baik, (2) Lebih padat, (3) Rasanya lebih gurih, (4) Kandungan lemak atau kolesterol lebih rendah. dan (5) Kandungan protein tinggi (Welsh, 1995). Selain itu, konsumen lebih memilih daging segar dan keabsahan pemotongan. Hal yang sama juga terjadi pada konsumen ayam buras/kampung (native chicken) di Filipina, dimana mereka lebih menyukai ayam buras karena rasanya lebih enak dan kandungan lemaknya yang rendah (Gonzales, 1999).

Kelebihan lain dari pada ayam buras dibandingkan dengan ayam ras adalah dalam hal pemakaian obatobatan. Harga obat-obatan yang semakin mahal telah memicu peternak ayam buras untuk menggunakan obatobatan tradisional. Pada umumnya mereka sudah tidak sanggup lagi membeli obat-obatan buatan pabrik. akibat harga obat-obatan ayam buatan pabrik yang terlalu tinggi untuk dijangkau peternak ayam buras (Noerdjito, 1985), Ditinjau dari bahan dasar obat, terlihat bahwa bahanbahan tersebut mudah diperoleh di sekitar rumah karena bahan-bahan tersebut terdiri dari bahan makanan, bumbu dapur, bahan makan sirih dan bahan obat tradisional bagi manusia yang sedang digalakkan penyediaannya dalam apotek hidup.

\section{Keragaan Usaha Ternak Ayam Buras}

\section{Usaha Ternak Ayam Buras Sebagai Usaha Ekonomi}

Secara alami ayam buras dalam mencukupi keseimbangan kebutuhan nutrisi pakan pada pemeliharaan secara tradisional (ekstensif) berasal dari sumber daya yang tersedia di lingkungan sekitarnya. Adanya perubahan pola pemeliharaan menuju semi intensif bahkan intensif dewasa ini berarti mengubah lingkungan hidupnya. Pemeliharaan intensif dengan pemberian pakan secara rasional memberikan respons positif meskipun aspek ckonomisnya perlu dikaji (Wihandoyo dan Mulyadi, 1985), sedangkan semakin intensif pemeliharaan yang dilaksanakan akan cenderung semakin tinggi ketergantungan peternak terhadap input produksi dari luar (Sabrani, 1986).

Patokan kebutuhan untuk nutrisi pada pakan ayam buras di Indonesia masih belum ada yang pasti, sedangkan dasar penyusunan ransum pada umumnya masih menggunakan kisaran yang direkomendasikan oleh Nutrient Research Council (1977). Pemerintah menetapkan kandungan protein ransum untuk ayam ras petelur sebesar 16 persen. Berdasarkan perkiraan patokan nutrisi tersebut, biaya pakan sebagai komponen input dapat mencapai $60-70$ persen bahkan lebih (Suroprawiro, Siregar dan Sabrani, 1985) mengingat harga pakan sangat berfluktuasi.

Terdapat tiga sistem pemeliharaan dalam usaha ternak ayam buras, yakni : (1) Sistem pemeliharaan ekstensif (tradisional) yang umum dilakukan rumah tangga di pedesaan dengan produksi yang masih rendah, ayam tidak dikandangkan, pakan seadanya yang dapat diperoleh di sekitar pekarangan petani dan pada sistem ini belum diperhatikan aspek teknis maupun perhitungan ekonomisnya; (2) Sistem pemeliharaan semi intensif. Dalam sistem ini sudah disediakan kandang dengan pagar di sekeliling tempat ayam berkeliaran, telah dilakukan penyapihan anak ayam dari induknya dan diberikan pakan tambahan; (3) Sistem pemeliharaan intensif adalah sistem pemeliharaan dimana ayam sudah 
dikurung sepanjang hari dengan pemberian pakan dan pencegahan penyakit yang dilakukan secara teratur dan intensif. Gonzales (1999) menyatakan bahwa dengan memberikan beberapa inovasi dan perbaikan-perbaikan pada sistem usaha temak tradisional, ayam buras dapat memproduksi lebih dari 200 butir dan mencapai berat badan $1 \mathrm{~kg}$ dalam 12 minggu. Dalam analisis ayam buras yang dipelihara secara intensif di Jawa Timur didapatkan keuntungan per bulan Rp 86937,57 untuk pemilikan rata-rata 97,3 ekor (Muryanto, Subiharta dan Juwono, 1985). Sementara pada pemeliharaan ayam buras secara intensif di Provinsi Bali, dengan skala usaha yang lebih besar (500 ekor) didapatkan keuntungan sebesar Rp 375984 per bulan (Sayuti, 1994).

Untuk dapat meningkatkan produksi ayam buras, maka faktor pemberian pakan perlu diperhatikan, baik dari segi kuantitas maupun kualitas sehingga dapat memberikan hasil optimal. Berdasarkan klasifikasi penyusunan ransum maka bahan pakan ternak unggas dibagi kedalam beberapa klasifikasi yaitu: sumber karbohidrat (jagung, singkong, putak, talas), sumber protein nabati dan hewani, sumber vitamin dan mineral. Sumber karbohidrat utama adalah serealia dan umbiumbian dengan kandungan pati yang berbedabeda seperti : jagung 72,4 persen, singkong 34 persen dan talas 40 persen (Umar. Fuah dan Bamualim, 1989 dan Bamualim dan Mommuat, 1989).

Dewasa ini jagung merupakan salah satu makanan ternak yang utama karena digunakan sebagai salah satu komponen ransum yang kaya akan karbohidrat. Akan tetapi penggunaan jagung sebagai pakan unggas bersaing dengan kebutuhan manusia, terutama di Pulau Timor dimana jagung merupakan bahan makanan pokok, sama halnya dengan kacang kedelai di Pulau Jawa sebagai bahan dasar untuk membuat tempe dan tahu. Untuk mengatasi hal tersebut maka perlu dicari altematif bahan pakan lain yang dapat digunakan untuk mengurangi penggunaan jagung dalam ransum ternak unggas, khususnya ternak ayam.

Salah satu bahan pakan pengganti yang dapat digunakan sebagai sumber karbohidrat adalah putak (isi batang pohon gewang). Menurut Bamualim dan Momuat, (1989) putak adalah salah satu bahan pakan sumber karbohidrat yang mengandung energi cukup tinggi, disukai oleh ternak sapi, kambing, babi dan ayam. Mustafa (1989) melaporkan bahwa pemberian putak dengan level 75 persen dapat menggantikan posisi jagung dalam ransum ternak babi. Sedangkan hasil penelitian Gasper dan Nenot (1989) pada ayam pedaging dengan level 40 persen dari total tidak memberikan pengaruh yang negatif. Hasil penelitian Umar, Fuah dan Bamualim, (1989) memperlihatkan bahwa penggunaan putak dalam ransum ayam buras dapat menekan penggunaan jagung sampai batas $0-30$ persen dari total ramsum. Untuk periode bertelur maka penggunaan jagung minimal 10 persen dari total ransum sebagai karoten dan xantophyl yang sangat dibutuhkan dalam produksi telur dan pembuatan kuning telur.

Produktivitas ayam buras yang dipelihara secara tradisional pada umumnya masih rendah. Hasil pengamatan sebelumnya menunjukkan bahwa produksi telur /induk/periode bertelur berkisar $6-10$ butir, daya tetas 40-83 persen dan setahun bertelur 
selama tiga periode schingga produksi telur per tahun berkisar 18-30 butir.

Dengan perbaikan teknologi pemeliharaan yang diintroduksikan (tatalaksana perkandangan, pemisahan anak segera setelah menetas dan pengendalian penyakit) menunjukkan peningkatan produktivitas yang relatif kecil. Rendahnya daya tetas dapat dipengaruhi oleh telur yang tak terbuahi, kualitas pakan, umur ayam, pengaruh musim, pengaruh waktu perkawinan, hormon, besar/berat telur, kualitas kulit telur, pengaruh penyakit dan kondisi lingkungan/sarang penetasan yang kurang mendukung.

Dalam hubungan antara bentuk sangkar dengan penetasan telah dianjurkan untuk membuat sangkar bentuk kerucut. Bahan sangkar kerucut dapat dibuat dari bambu yang dibelah kecil-kecil dan dibentuk kerucut dan biaya pembuatan serta ketersediaan bambu relatif murah dan mudah didapat. Dari hasil monitoring ternyata daya tetas telur yang dieramkan adalah 72,06 - 80,21 persen. Secara umum produksi telur per periode bertelur (clutch) pada ayam buras berkisar $8-12$ butir. Dengan rataan periode bertelur/tahun sebanyak 4 kali, berarti produksi telur/induk/tahun berkisar 38-48 butir.

Dari beberapa pengamatan terdahulu (Prasetyo, Dirdjopratono dan Sabrani, 1985), dilaporkan bahwa produksi telur/induk/tahun berkisar $50-60$ butir. Masih rendahnya kapasitas produksi telur pada ayam buras yang dipelihara secara tradisional adalah karena induk dibiarkan mengasuh anaknya sampai disapih selama tiga bulan. Oleh karena faktor pembatas teknis utama produktivitas telur adalah periode (lama waktu) mengasuh anak sampai sapih ( 3 bulan) maka salah satu cara untuk meningkatkan produktivitas induk adalah dengan teknologi pemisahan anak ayam segera setelah menetas. Beberapa hasil penelitian menunjukkan bahwa perbaikan teknologi budidaya mampu meningkatkan produksi telur, produksi anak ayam dan mengatasi beberapa permasalahan yang menyebabkan rendahnya produktivitas ayam buras.

Hasil penelitian menunjukkan bahwa vaksinasi secara teratur empat bulan sckali dapat mengurangi kematian ayam menjadi 50 persen (Nataamijaya dan Jarmani, 1993); dan di daerah transmigrasi dilaporkan vaksinasi secara teratur dapat menurunkan kematian ayam buras dari 72 persen menjadi 53,5 persen atau bahkan turun menjadi 29.1 persen apabila disertai dengan pemisahan anak dari induk (Nataamijaya et.al, 1986). Pemeliharaan secara intensif dengan teknik pisah anak secara dini dapat meningkatkan produksi anak minimum 70 ekor anak/tahun (Braman, 1991).

Hasil penelitian Kingstone (1979) pada ayam buras yang dikembangkan sebagai ayam potong terutama untuk ayam jantan memperlihatkan bahwa ayam buras jantan yang dipelihara di pedesaan secara tradisional pada umur 20 minggu mempunyai bobot badan $1027 \mathrm{~g}$, sementara yang dipelihara secara intensif menghasilkan bobot badan $1718 \mathrm{~g}$. Keuntungan yang dipelihara secara intensif setiap dua bulan adalah sebesar Rp 627,00/ekor. Sayuti (2001) melaporkan bahwa pemeliharaan ayam secara intensif lebih menguntungkan dibandingkan pemeliharaan yang ektensif. Hal ini memperlihatkan bahwa ayam buras dapat dikembangkan sebagai usaha ekonomi. Beberapa faktor penghambat adalah antara lain skala usaha relatif kecil dan investasi sangat rendah 
dengan kemampuan yang kecil, peternak tidak mungkin bersaing dengan usaha-usaha lain yang membutuhkan bahan baku yang sama. Pendidikan peternak pada umumnya masih rendah. Dengan kondisi semacam itu peternak hanya mampu menguasai proses produksi sepenuhnya, tetapi sangat lemah dalam hal pemasaran dan memperoleh bahan baku pakan. Selain itu Pelayanan pemerintah bagi pengembangan usaha ayam buras masih sangat terbatas pada kegiatankegiatan penyuluhan dan bimbingan. Belum terdapat kegiatan yang mendorong terciptanya agribisnis bagi usaha rakyat ayam buras, seperti pelayanan kredit, penelitian dan sebagainya.

\section{Penutup}

Diskusi di atas memberikan peringatan bahwa temak ayam lokal yang sebagian besar dipelihara secara ektensif sebenarnya dapat menjadi sumber lapangan kerja dan pendapatan bagi rakyat pedesaan. Sekali pun pada kenyataannya ayam buras itu mempunyai sifat-sifat ekonomi yang relatif rendah dibandingkan ayam ras petelur dan pedaging, namun produksi ayam buras mempunyai nilai ekonomi yang tinggi. Bahkan nilai ekonomi produksi ayam buras cenderung terus meningkat dari tahun ke tahun karena produksi ayam buras bebas residu obat-obatan, antibiotika dan sebagainya.

Pemerintah sebaiknya mengarahkan perhatian yang lebih besar terhadap pengembangan ayam buras secara ekonomi. Antara lain melalui pembinaan pada peternak, memberikan fasilitas kredit yang murah dan mendorong terbentuknya koperasi peternak ayam buras. Koperasi ini akan berfungsi sebagai agribisnis tetapi tetap menekankan bahwa keuntungan sebesar-besarnya dimiliki oleh peternak.

\section{Daftar Pustaka}

Biro Pusat Statistik. 2004. Pengeluaran Untuk Konsumsi Penduduk Indonesia. SUSENAS, Jakarta.

Dinas Peternakan Provinsi Sumatera Barat. 2005. Statistika Peternakan Provinsi Sumatera Barat 2005. Padang.

Braman, F. 1991. Bagaimana Mempercepat Peningkatan Produksi Ayam Buras, Ayam dan Telur No. 61.

Daslina, 1992. Analisa Permintaan Daging Sapi, Kerbau, Kambing, Ayam Ras dan Ayam Buras di Kabupaten Bogor. Karya Ilmiah. Fakultas Peternakan. Bogor.

Djatmiko, D.H. dan E. Sugiharti. 1986. Beternak Ayam Kampung. Cetakan 1. Penerbit PT Simplex, Jakarta.

Gonzales, S. 1999. Experts Prefer "Native Chicken". Inquirer. Philippine Daily, 3 October 1999

Kingstone, D.J. 1979. Peranan Ayam Kampung Berkeliaran di Indonesia. Laporan Seminar Ilmu dan Industri Perunggasan II. Bogor.

Mansjoer, S.S. 1989. Pengkajian Sifatsifat Produksi Ayam Kampung Serta Persilangannya dengan Ayam Rhode Island Red. Disertasi. Fakultas Pasca Sarjana IPB, Bogor. 
Marhijanto, 1996. Beternak Ayam Buras. Penebar Swadaya. Jakarta.

Muryanto. 1989. Perkembangan dan Produktivitas Ayam Buras di Indonesia. Prosiding Seminar Nasional Tentang Unggas Lokal. Fakultas Petemakan. Universitas Diponegoro. Semarang.

Mustafa, H. 1989. Pengaruh Pemberian Putak Sebagai Pengganti Jagung dalam Ransum Terhadap Pertumbuhan Berat Badan Anak Babi Peranakan VDL. Thesis Fakultas Peternakan Undana, Kupang.

Nataamijaya, A.G., D. Sugandhi, D. Muslich, U, Kusnadi, H. Supriyati dan 1.G. Ismail. 1986. Peningkatan Keragaan Ayam Buras di Daerah Transmigrasi Batumarta, Sumatera Selatan. Risalah Lokakarya Pola Usahatani, Badan Litbang Pertanian. Jakarta.

Nataamijaya, A.G., P. Sitorus, I.A.K. Bintang, Haryono dan E. Bunyamin. 1993. Pertumbuhan Badan Ayam Silangan (Pelung $x$ Kampung) yang Dipelihara di Pedesaan Dalam "Laporan Hasil Penclitian Program Konservasi Ayam Buras Langka". Puslitbang Tanaman Pangan. Bogor.

Noerdjito, M. 1985. Perlu Diungkap Lebih Lanjut : Ramuan dan
Khasiat Obat Tradisional Bagi Ayam. Lembaga Biologi Nasional, LIPI, Bogor.

Pond, W.G. 1980. Animal Agriculture Research to Meet Human in the 21 Century: 28 . West View Press, Inc.

Sabrani, M. 1986. Altematif Teknologi dan Pengembangan Ayam Buras, Hasil Temu Tugas. Pengembangan Ayam Buras di Jawa Tengah. Balai Informasi Pertanian. Ungaran. Sarwono, B. 1996. Tujuh Langkah Beternak Ayam Buras. Arloka. Surabaya.

Sayuti, R, 1994. Analisis Usaha Ternak Pola Ekstensif Semi Intensif. Hasil Temu Tugas Dalam Aplikasi Teknologi di Timor-Timur pada tanggal 28 Februari-2 Maret 1994.

Sayuti, R. 2001. Analisis Agribisnis Ayam Buras Melalui Pendekatan Fungsi Keuntungan Multi Output (Kasus Jawa Timur). Disertasi Program Pasca-sarjana Universitas Padjadjaran. Bandung.

Umar, A., M. Fuah, dan A. Bamualim. 1989. Pengaruh Kombinasi Beberapa Level Putak dan Jagung dalam Ransum Terhadap Pertumbuhan Ayam Buras. Sub Balai Penelitian Ternak Lily, Kupang. Nusa Tenggara Timur.

Alamat korespondensi; Rahmi Wati, S,Pt, M.Si

Jurusan Produksi Ternak, Fakultas Peternakan

Universitas Andalas, Kampus Limau Manis, Padang

Telp. 0751-74208 Fax: 0751-71464, HP: 08197525102

Diterima: 8 Mei 2007, Disetujui: 23 Mei 2007 